\title{
2.4.4. Kształtowanie pozytywnych relacji uczniów w edukacji włączającej
}

DOI: $10.47050 / 65591838.218-226$

Jacek Pyżalski

\section{Dziecko ze specjalnymi potrzebami w grupie rówieśniczej}

Funkcjonowanie dziecka ze specjalnymi potrzebami w grupie stanowi zwykle spore wyzwanie zarówno dla niego samego, jak i dla innych jej członków. Problemy dotyczące relacji rówieśniczych są od dawna dostrzegane i omawiane w literaturze światowej. Już w 2006 r. Chris Forlin pisał na temat szkół australijskich: „Jest ogólnie przyjętą prawdą, że zespoły klasowe są obecnie bardziej zróżnicowane niż kiedykolwiek wcześniej, a nauczyciele mogą się spodziewać, że będą musieli pracować z uczniami o szerokiej gamie potrzeb, nie tylko związanych z niepełnosprawnością, ale także z takimi, którzy mogą być wykluczani z wielu innych przyczyn" (Forlin 2006, s. 271). Wykluczenie, o którym tu mowa, wynika właśnie z postaw i działań rówieśników wobec dziecka ze specjalnymi potrzebami.

Piotr Plichta (2016) wskazuje, że w legislacji specjalne potrzeby w Polsce definiowane są bardzo szeroko (a do tego nie są nazywane wprost) i obejmują dzieci wymagające dostosowania rozwiązań wychowawczych i dydaktycznych. Odnoszą się one zatem do bardzo zróżnicowanych podgrup, czyli osób:

$\rightarrow$ niepełnosprawnych, niedostosowanych społecznie i zagrożonych niedostosowaniem społecznym: niesłyszących, słabosłyszących, niewidomych, słabowidzących, z niepełnosprawnością ruchową, w tym z afazją, z niepełnosprawnością intelektualną w stopniu lekkim, umiarkowanym lub znacznym, z autyzmem, w tym z zespołem Aspergera, i z niepełnosprawnościami sprzężonymi; 
$\rightarrow$ niedostosowanych społecznie lub zagrożonych niedostosowaniem społecznym;

$\rightarrow$ przejawiających szczególne uzdolnienia;

$\rightarrow$ doświadczających specyficznych trudności w uczeniu się;

$\rightarrow$ z zaburzeniami w komunikacji językowej;

$\rightarrow$ chorujących przewlekle;

$\rightarrow$ które przeżyły sytuacje kryzysowe lub traumatyczne;

$\rightarrow$ zmagających się z niepowodzeniami edukacyjnymi;

$\rightarrow$ które doświadczyły zaniedbań środowiskowych wynikających z sytuacji bytowej rodziny, sposobu spędzania czasu wolnego i kontaktów w najbliższym otoczeniu;

$\rightarrow$ z trudnościami adaptacyjnymi związanymi z różnicami kulturowymi lub ze zmianą środowiska edukacyjnego, w tym wynikającymi z wcześniejszego kształcenia za granicą.

Lista ta nie jest oczywiście wyczerpana, a specjalne potrzeby mogą dotyczyć także innych grup lub występować łącznie, co zawsze będzie przekładać się na indywidualną sytuację dziecka - jego wizerunek wśród rówieśników i relacje z kolegami. Osoby z wymienionych podgrup mają częściej problemy emocjonalne oraz obniżone umiejętności społeczne. Oczywiście ich głębokość oraz charakter mogą być zróżnicowane i w pewnym zakresie specyficzne dla określonej zbiorowości (np. Baker, Donelly 2001; Bejerot, Edgar, Humble 2011; Kaukiainen i in. 2002; Reiter, Lapidot-Lefler 2007).

W warunkach szkolnych mamy tu do czynienia z sytuacją zespołu klasowego, w którym pojawia się dziecko funkcjonujące -z różnych powodów -w sposób odmienny od rówieśników. Budzi to zwykle w innych dzieciach emocje, które mogą stanowić przeszkodę w budowaniu relacji oraz komunikacji (Forlin, Chambers 2003). To właśnie te emocje, a także słabe relacje i brak kompetencji w zakresie codziennej komunikacji z „innym" rówieśnikiem, są często $w$ dłuższej perspektywie podstawą budowania negatywnych postaw wobec niego. Oczywiście postawy takie mogą być także obecne wcześniej i wynikać z oddziaływań szerszego środowiska, np. społecznych postaw wobec osób z niepełnosprawnością lub obcokrajowców. Nastawienia takie budują niekorzystny klimat, a także eskalują, przekładając się na codzienne postępowanie dzieci wobec „innego" rówieśnika.

Najgorsza sytuacja jest wtedy, gdy pojawia się przemoc rówieśnicza, której ofiarą pada dziecko ze specjalnymi potrzebami. Może mieć ona 
charakter fizyczny (bicie, niszczenie własności), werbalny (przezywanie, grożenie), elektroniczny (cyberprzemoc - przemoc przy użyciu technologii informacyjno-komunikacyjnych) oraz relacyjny (wykluczanie z grupy) (Pyżalski 2012). Wyniki badań światowych potwierdzają, że zaangażowanie dzieci ze specjalnymi potrzebami edukacyjnymi w proces nękania (bullying) jest wyższe (często kilkukrotnie) w porównaniu ze wskaźnikami u pozostałych rówieśników (por. Plichta 2016). Należy tu jednocześnie wskazać, że wbrew obiegowym opiniom dzieci ze specjalnymi potrzebami częściej stają się nie tylko ofiarami, ale także sprawcami przemocy rówieśniczej (ze względu choćby na często występujący niedostatek umiejętności społecznych), szczególnie wtedy, gdy nie mogą poradzić sobie z doświadczeniami wynikającymi z wcześniejszej wiktymizacji (Plichta, Olempska-Wysocka 2013; Plichta, Olempska-Wysocka 2014; Pyżalski 2012).

Warto zauważyć, że najpoważniejszy typ przemocy rówieśniczej - nękanie - przekłada się na poważne konsekwencje dotyczące wszystkich zaangażowanych, tj. sprawców, ofiar i świadków. Mamy z nim do czynienia, gdy wrogie działania mają charakter długotrwały, intencjonalny i wiążą się z przewagą sprawców. W sytuacji włączania do grupy dzieci o specjalnych potrzebach edukacyjnych ta ostatnia właściwość jest często automatycznie wpisana w sytuację. Nierównowaga sił może wynikać tu z mniejszej siły fizycznej ofiary, trudności poznawczych, trudności komunikacyjnych lub problemów w sferze emocjonalnej, które upośledzają zdolności obrony przed napastnikami (Pyżalski 2012). Niestety, konieczność dostosowania programów zapobiegających nękaniu do potrzeb dzieci ze specjalnymi potrzebami edukacyjnymi jest często ignorowana (Raskausas, Modell 2011).

Chcąc przeciwdziałać przemocy rówieśniczej, powinniśmy zatem szukać rozwiązań dotyczących wszystkich zaangażowanych osób - nie tylko sprawców i ofiar, ale także pozostałych uczniów, którzy bezpośrednio nie biorą udziału $w$ tym procederze. Należy ponadto przyjąć, że najbardziej skuteczne są działania zapobiegawcze realizowane wtedy, kiedy jeszcze nie pojawiły się poważne oznaki przemocy wobec dziecka ze specjalnymi potrzebami edukacyjnymi. Im dłużej ta przemoc trwa, tym poważniejsze będą jej przejawy. Towarzyszyć im będzie także pogłębienie postaw wrogości wobec ofiary. Wszystko to sprawia, że nawet bardzo profesjonalne i dobrze przeprowadzone działania na dalszych etapach procesu nękania są często nieefektywne. 


\section{Jak kształtować pozytywne postawy uczniów wobec rówieśników ze specjalnymi potrzebami?}

Kiedy mówimy o kształtowaniu pozytywnych postaw i stwarzaniu warunków budowania korzystnych relacji z rówieśnikami ze specjalnymi potrzebami, w pierwszej kolejności mamy na uwadze zajęcia edukacyjne dla uczniów, które ich odpowiednio ukształtują i z których wyniosą odpowiednią wiedzę i pożądane umiejętności. Takie ujęcie ma jednak poważne ograniczenia, postawy bowiem formują się w wyniku codziennych doświadczeń, których oddziaływanie jest silniejsze niż nawet najlepiej zaplanowane szkolenia. W dalszej części tekstu przedstawiam istotne czynniki oddziaływania pedagogicznego i propozycje rozwiązań, które mają pozytywne przełożenie na relacje rówieśnicze z dzieckiem ze specjalnymi potrzebami edukacyjnymi (Krajewski, Hyde 2000).

\section{Nauczyciel jako wzór}

Dzieci poznają wiele rzeczy przez obserwację. Z tego względu bardzo istotna jest świadomość nauczyciela w zakresie jego rzeczywistych postaw i emocji związanych z pracą z podopiecznym ze specjalnymi potrzebami edukacyjnymi. Badania wskazują, że wielu pedagogów ma obawy w zakresie własnych kompetencji wychowawczych i dydaktycznych związanych z pracą z dziećmi z takimi potrzebami (Sudal-Malukiewicz 2001; Plichta, Olempska-Wysocka 2013; 2014). W takiej sytuacji postawa nauczyciela może przejawiać się behawioralnie w formie określonych reakcji emocjonalnych i działań związanych z zachowaniem ucznia ze specjalnymi potrzebami edukacyjnymi. Jeśli reakcje te naznaczone są silnymi emocjami lub bezradnością, albo kiedy nauczyciel odbiera zachowania ucznia jako przejawy wrogości, jego podopieczni mogą ulegać tym negatywnym emocjom. W rezultacie mogą wykazywać podobne zachowania i postawy wobec rówieśnika ze specjalnymi potrzebami edukacyjnymi. Ważne zatem, by nauczyciel uświadamiał sobie własne przeżycia oraz reakcje, a także żeby zdawał sobie sprawę, że nawet kiedy tego nie przewiduje, jest dla uczniów wzorem do naśladowania.

Pedagog, który rozumie funkcjonowanie dzieci ze specjalnymi potrzebami, wie, jak reagować w sytuacjach dla nich trudnych, jak je wspierać, jak tłumaczyć ich potrzeby pozostałym uczniom $w$ taki sposób, by nie pojawiały się u nich negatywne emocje i postawy wobec 
rówieśników z tej grupy (Healy 2014). Prawidłowości tu przedstawione, choć dotyczą głównie nauczycieli (w tym tzw. wspierających), można odnieść w pewnym zakresie do wszystkich osób dorosłych w szkole, w tym do personelu pomocniczego i administracyjnego. Ich działania i zachowania wobec dzieci z omawianej grupy także są obserwowane przez pozostałych uczniów.

Przy tego rodzaju zastrzeżeniach podstawową kwestią dla kształtowania postaw uczniów będzie postawa samego nauczyciela oraz jego przygotowanie do pracy z osobami ze specjalnymi potrzebami edukacyjnymi. Postawy nauczyciela i uczniów należy traktować jako naczynia połączone, trudno bowiem wyobrazić sobie, że pedagog skutecznie stosuje jakieś rozwiązania edukacyjne kształtujące podopiecznych, a jednocześnie sam prezentuje postawę negatywną. Przygotowanie praktyczne nauczyciela, związane przede wszystkim ze zrozumieniem i znajomością potrzeb osób ze specjalnymi potrzebami edukacyjnymi, należy traktować jako warunek sine qua non efektywnego formowania postaw innych uczniów wobec tej grupy. W uproszczeniu, ten obszar oddziaływań oznacza, że im częściej uczniowie będą obserwować pozytywne, pełne szacunku podejście swojego nauczyciela wobec dzieci ze specjalnymi potrzebami edukacyjnymi, tym większe będzie prawdopodobieństwo, że sami będą zachowywać się podobnie.

\section{Współpraca z rodzicami}

Inną grupą osób dorosłych, których postawy mogą mieć przełożenie na działania uczniów, są rodzice. Jeżeli uważają oni, że obecność osób ze specjalnymi potrzebami edukacyjnymi w zespołach klasowych obniża jakość dydaktyki lub stanowi niebezpieczeństwo dla pozostałych uczniów, może się to przełożyć na postawy ich dzieci. W wielu sytuacjach i w różny sposób rodzice komunikują tego typu podejście, nawet jeżeli nie bezpośrednio swoim dzieciom, to np. w ich obecności. Istotne jest zatem podejmowanie wyprzedzająco działań informacyjnych w sprawie specjalnych potrzeb uczniów w zespołach klasowych, ale także w zakresie tego, co robić, jeśli do rodziców dotrą wiadomości o pojawiających się sytuacjach nękania lub problemach interpersonalnych dotyczących relacji między dziećmi (Pyżalski 2018). Współpraca ta powinna dotyczyć także rodziców ucznia włączanego, choćby po to, by wszelkiego rodzaju problemy w interakcjach rówieśniczych diagnozować i rozwiązywać na wczesnym etapie. 
Rozpoczynając współpracę z rodzicami, pracownicy szkoły mogą przekazywać im informacje podczas zebrań klasowych, ale też z wykorzystaniem materiałów edukacyjnych dystrybuowanych $w$ formie papierowej lub elektronicznej. Mogą to być:

1. Wskazówki dotyczące postępowania w sytuacji, gdy rodzice dowiedzą się o problemach w relacjach klasowych (bez względu na rolę, jaką odgrywa ich dziecko - sprawcy, ofiary czy świadka). Warto tu wyraźnie wskazać, że działania na wczesnym etapie, podejmowane we współpracy szkoły z rodzicami, przynoszą najlepsze efekty;

2. Kwestie dotyczące planowanych działań (także formalnych) inicjowanych przez szkołę w sytuacji, gdy pojawią się poważne przypadki przemocy rówieśniczej. Podejście takie jest transparentne i sprawia, że w razie zastosowania określonej wcześniej procedury jest ona traktowana jako naturalna konsekwencja, a nie arbitralne działanie placówki;

3. Informacje o potrzebach oraz ważnych aspektach funkcjonowania dziecka ze specjalnymi potrzebami i związanymi z tym działaniami (np. określone miejsca siedzenia w klasie, dostosowane sposoby sprawdzania wiedzy, specyficzne uwarunkowania komunikacyjne ucznia). Zanim tego typu wiadomości zostaną rozpowszechnione, muszą być ustalone i skonsultowane z rodzicami dziecka ze specjalnymi potrzebami edukacyjnymi.

\section{Organizacja sesji edukacyjnej}

\section{na temat specyfiki specjalnych potrzeb}

Wiele problemów związanych z akceptacją i nawiązywaniem przyjaźni z dziećmi ze specjalnymi potrzebami edukacyjnymi wynika z tego, że rówieśnicy nie rozumieją pewnych ograniczeń dotyczących tej grupy. Sprawdzonym rozwiązaniem, które może zapobiegać pojawianiu się tego typu kłopotów, są sesje edukacyjne dla rówieśników ucznia ze specjalnymi potrzebami edukacyjnymi. Ważne jest, by były one dostosowane do wieku uczestników i koncentrowały się na przekazywaniu konkretnych, praktycznych porad, dotyczących choćby zachowania się w codziennych sytuacjach (np. „Kiedy mówisz do kolegi, który słabo słyszy, musisz stanąć naprzeciwko niego, żeby cię widział”). Takie zasady, pozornie oczywiste, nie muszą być jasne dla większości dzieci, szczególnie w młodszych klasach szkoły podstawowej. 
Tego rodzaju zajęcia są często nazywane sesjami uświadamiania o niepełnosprawnościach (disability awareness sessions) (Raskauskas, Modell 2011). Oczywiście szkolenia mogą także dotyczyć uczniów, którzy znajdują się w innej sytuacji, np. dzieci z rodzin imigranckich. Najważniejsze, by były wprowadzane w uzgodnieniu z dziećmi i ich rodzicami, a nie narzucane przez nauczyciela (Healy 2014). Niektórzy uczniowie mogą sami (przynajmniej w pewnym zakresie) poprowadzić tego typu sesje, np. dzieci, które przyjechały z innego kraju są w stanie opowiedzieć o swojej kulturze, zaprezentować powiązane z nią przedmioty.

Uczniowie mogą także określić swoje oczekiwaniach wobec innych. Ma to szczególne znaczenie podczas wprowadzania nowego ucznia do funkcjonującego zespołu klasowego - w takiej sytuacji ryzyko nieprzyjęcia go do grupy i prawdopodobieństwo odrzucenia są szczególnie wysokie, nawet w przypadku dzieci bez specjalnych potrzeb edukacyjnych.

Wdrażając te rozwiązania należy zawsze pamiętać, że dotyczą one kwestii drażliwych i budzą zainteresowanie, ale także wywołują silne emocje. Warunkami skutecznego działania w tym zakresie są: odpowiedni styl komunikacji nauczyciela podczas sesji dla dzieci, jego autentyczne zainteresowanie, obserwowanie reakcji dziecka ze specjalnymi potrzebami edukacyjnymi oraz innych uczniów, a także adekwatne reagowanie na nie. Opisywane w tej części sesje edukacyjne mają bardzo duży potencjał edukacyjny, mogą jednak także bardzo zaszkodzić, gdy są realizowane nieumiejętnie.

\section{Stwarzanie okazji do codziennych interakcji i współpracy}

Kluczowym czynnikiem przyczyniającym się do budowania pozytywnych postaw wobec dzieci ze specjalnymi potrzebami edukacyjnymi jest stwarzanie przez nauczyciela okazji do interakcji i budowania więzi rówieśniczych. Chodzi tu głównie o działania, w ramach których wszyscy uczniowie mają okazję przebywać w grupie i wspólnie pracować, szczególnie z dziećmi ze specjalnymi potrzebami edukacyjnymi.

Wśród rozwiązań w tym zakresie wymienić można: przesadzanie uczniów w ławkach, by każdy z każdym mógł przez jakiś czas dzielić wspólną przestrzeń, tworzenie zespołów, w których dzieci wykonują określone zadania, lub organizowanie zabaw polegających na tym, że uczniowie robią coś na rzecz osoby, którą wylosowały. Te pozornie proste interakcje wymagają bardzo kompetentnego i refleksyjnego wdrażania. Nawet drobne elementy mogą zadecydować o tym, 
czy rozwiązania okażą się skuteczne. Na przykład, przesadzając uczniów w ławkach, trzeba pamiętać o określonych elementach metodycznych:

$\rightarrow$ procedurę wprowadza się w nowym zespole klasowym, nim uczniowie zdążą się przyzwyczaić do dzielenia ławki z jedną osobą - w takiej sytuacji zmiana miejsca w klasie traktowana jest jako naturalna i nie budzi kontrowersji;

$\rightarrow$ uczniowie muszą być powiadomieni, że z każdym kolegą i każdą koleżanką siedzą czasowo i że regularnie będą następowały zmiany;

$\rightarrow$ konfiguracje dotyczące tego, kto z kim siedzi, ustalane są losowo. W takiej sytuacji rzadziej dochodzi do konfliktów z uczniami niż wtedy, gdy decyzje w tym zakresie arbitralnie podejmuje nauczyciel;

$\rightarrow$ konieczne jest uwzględnianie ograniczeń w zastosowaniu tej metody w wypadku specjalnych potrzeb (np. niektórzy uczniowie ze spektrum autyzmu nie powinni uczestniczyć w zmianach miejsc, uczniowie z problemami sensorycznymi muszą siedzieć w pierwszych rzędach w sali);

$\rightarrow$ rodzice uczniów przed wprowadzeniem procedury przesadzania muszą być powiadomieni o takim rozwiązaniu i jego celach. Gdy ten aspekt zostanie zaniedbamy, mogą wystąpić konflikty z osobami, które tego typu działania mogą uznać za niepotrzebne i budzące negatywne emocje dzieci.

Trzeba jednak pamiętać, że aby rozwiązania mogły być skuteczne, muszą być wdrażane na odpowiednim etapie, czyli wtedy, gdy postawy wobec dziecka włączanego są neutralne. Nie można ich stosować w momencie, gdy uczeń stał się ofiarą nękania. Ich wprowadzenie w momencie, gdy problem odrzucenia lub przemocy już występuje, może jedynie pogorszyć sytuację ofiary. Oznacza to, że nauczyciel pracujący w edukacji włączającej musi być proaktywny i podejmować stosowne kroki, zanim pojawią się kłopoty związane z relacjami rówieśniczymi.

\section{Przygotowanie ucznia ze specjalnymi potrzebami edukacyjnymi}

Na postawy klasy wpływają także działania podejmowane przez samego ucznia ze specjalnymi potrzebami edukacyjnymi (lub jego bierność). W wielu sytuacjach pomocne mogą się okazać działania edukacyjne lub doradcze wspierające takie dziecko. Efektem tego wsparcia 
może być zwiększenie jego kompetencji komunikacyjnych, co umożliwi mu lepszy kontakt z rówieśnikami. Tego rodzaju oddziaływania mogą się również przyczynić do zredukowania zachowań, które są przez rówieśników odbierane jako prowokacyjne czy agresywne - praca w tym zakresie może dotyczyć np. korygowania sposobu współpracy dziecka z rówieśnikami (np. podczas zapraszania do zabawy), jego reakcji na zaczepki lub konflikty, a także zachęcenia go do poszukiwania wsparcia dorosłych, gdy nie umie samodzielnie rozwiązać pojawiających się problemów (przy założeniu, że pomagają oni tylko w takim stopniu, w jakim jest to niezbędne).

\section{Podsumowanie}

Na zakończenie rozważań dotyczących kształtowania postaw uczniów wobec rówieśników ze specjalnymi potrzebami, warto wskazać, że proponowane rozwiązania są zgodne z kluczowymi założeniami dobrych praktyk w zakresie inkluzji.

Tim Loreman (2007) w tekście Seven pillar of support for inclusive education (Siedem filarów wsparcia edukacji włączającej) wskazuje, że najistotniejszymi elementami są:

1. Budowanie pozytywnych postaw nauczycielskich wobec inkluzji, a przede wszystkim wobec dzieci włączanych.

2. Możliwości organizacyjne w szkołach, związane z elastyczną realizacją programu i zadań dydaktycznych (w kontekście specjalnych potrzeb dzieci i ich chęci osiągnięcia sukcesu edukacyjnego).

3. Aktywizacja środowiska zewnętrznego szkoły (głównie rodziców) na rzecz wspierania inkluzji.

Zaproponowane rozwiązania stanowią kluczowy element inkluzji, bez którego cały proces może okazać się porażką. 